\title{
The International Red Cross and Red Crescent Movement and Lessons from its Experience of War Surgery
}

\author{
Maj D J Vassallo \\ FRCS (Ed), RAMC \\ Senior Registrar in General Surgery
}

Cambridge Military Hospital, Aldershot, Hants GU11 $2 A N$

SUMMARY: This article describes the evolution, motivation and structure of the International Red Cross and Redw Crescent Movement, and its contribution to international humanitarian law. It explains the respective roles of its three components: the National Societies, the International Federation of Red Cross and Red Crescent Societies, and the International Committee of the Red Cross (ICRC). It highlights the ICRC's experience of war surgery and emphasises the relevance of this for the military medical services, especially for the training of military surgeons and anaesthetists.

\section{Introduction}

How does a military surgeon or anaesthetist in peacetime acquire and keep updated his or her skills in war surgery?

This article aims to show to the military medical services the value of voluntary postings to the war hospitals of the International Committee of the Red Cross. It also provides the necessary background information about the evolution, motivation and structure of the International Red Cross and Red Crescent Movement.

\section{The Story of an Idea \\ The Battle}

Friday the 24th June 1859 saw over 300,000 men engaged in the bloodiest battle in Europe since Waterloo, a battle which was to cost some 6000 lives and leave another 42,000 wounded. It was fought near Solferino in Lombardy, northern Italy by the combined forces of the French army under the Emperor Napoleon III and the Sardinian army under King Victor-Emmanuel, fighting for the cause of Italian independence, against the Austrian army led by the Emperor Franz-Josef.

By nightfall, when the defeated Austrians retreated from the scene of carnage, the plain was strewn with many thousands of wounded, dying and dead soldiers, with thirst and hunger adding to the torments of the injured. Many died abandoned on the battlefield, but over nine thousand wounded found their way to the nearby town of Castiglione della Stiviere, which was transformed into a vast improvised dressing station.

There a horrified Swiss businessman, Henri Dunant, laboured to organise some relief where it was most lacking. He collected volunteers to care for over five hundred wounded piled into a church, the Chiesa Maggiore, distributing food and water, dressing their wounds, and even taking messages for the victims' families. He was shaken to the core to find that only six
French army doctors were available for the whole nine thousand, and that this was the normal state of affairs aftew a battle.

In Memory of Solferino

Back in Geneva, haunted by his memories, Dunant inspired to write a book, "Un souvenir de Solferino" which was published in 1862 (1). He depicted the battleing poignant detail, sharing with his readers his depthgo feeling on discovering the hitherto suppressed humbers consequences of war. Dunant's heartfelt appeal - 'Wowid it not be possible, in time of peace and quiet, to fofng relief societies for the purpose of having care given to wounded in wartime by zealous, devoted and thoroughlyo qualified volunteers?" - struck a chord in hearts all oveßू Europe. One particularly dynamic Geneva lawyero Gustave Moynier, was galvanised into action and b $\overrightarrow{5}$ February 1863 had helped Dunant set up an "International Committee for Relief to Wounded Soldiers", with the aim of setting up these national relie? societies.

This Committee (which later became the "Internationat Committee of the Red Cross") was composed of five citizens of Geneva: General Guillaume-Henri Dufou (Commander-in-Chief of the Swiss Army, and renownes as the creator in 1831 of the Swiss flag), Gustave Moynie $\overrightarrow{5}$ (later to become president of the Committee for half $\mathbb{\text { }}$. century), Henri Dunant, Doctor Louis Appia (deeplis interested in military surgery, and author of the book "The् Ambulance Doctor or Practical Studies of the Wound\$ Inflicted by Firearms") and Doctor Theodore Maunoir ( 2 J 3).

\section{The Emblem}

Dunant made one further proposal: that the wounded 0 and all those carrying for them, should be regarded a neutral, even on the battlefield, and therefore be immune 
from attack (2). All that was required (sic) was a single protective emblem for all armies, that would be worn by everyone caring for the wounded, painted on ambulances, and flown over medical units. This emblem would confer upon them a new legal status of "neutrality".

\section{The Birth of the Red Cross $(2,4)$}

The "Committee of Five" called an International Conference in Geneva in October 1863. Enthusiastic support from all over Europe ensured the attendance of thirty-six delegates, including eighteen official representatives from fourteen governments. On the 29 th October 1863 ten Resolutions were adopted, defining the functions and working methods of the proposed National Committees for Relief to Wounded Soldiers.

Article 8 of these Resolutions stated that the voluntary medical personnel should wear in all countries, as a uniform distinctive sign, a white armlet with a red cross this sign being adapted from the Swiss flag with its colours reversed.

It was particularly fitting that it was General Dufour, creator of the Swiss flag, who conceived this other flag of universal honour.

These Resolutions are the founding charter of the Red Cross. Within two months the first Relief Society was formed in Wurtemberg, and nine more were formed in the first year.

The British Red Cross Society came into being in 1870 , as the "National Society for Aid to the Sick \& Wounded in War". It was formally renamed the Red Cross in 1905, received the Royal Charter in 1908, and it will celebrate its 125th birthday in 1995 .

\section{The First Geneva Convention (2-5)}

In order for Dunant's concept of "neutrality" to acquire binding legal status, it was necessary for it to be embodied in an international treaty, which could only be concluded by a conference convened by a government, so the International Committee dedicated itself to bringing this about. The Swiss Government willingly undertook to convene such a conference in Geneva, and after Napoleon III announced his support for it, delegates from twelve countries gathered in Geneva in August 1864.

Great Britain was represented by Dr Rutherford, Inspector General of Hospitals, and Sir Thomas Longmore, Professor of Military Surgery at the Army Medical School in Netley (5). Thus began the longstanding association between the British Army Medical Services and the Red Cross Movement.

The draft treaty prepared by Moynier was adopted with minimal changes, as the Geneva Convention of August 22, 1864, for the Amelioration of the Condition of the Wounded in Armies in the Field.

From now on ambulances, military hospitals and medical staff were to be "recognised as neutral and, as such, protected and respected by the belligerents. "Wounded or sick combatants, to whatever nation they belong, shall be collected and cared for".
At the same time the red cross on a white ground was officially recognised as the protective emblem of the military medical services, with the specific purpose of protecting those wounded in war and those who care for them.

\section{The Red Crescent (3-4)}

The red cross on a white ground has no religious significance, having been adopted purely as a tribute to Switzerland. However, during the Russo-Turkish war of 1876, the Ottoman Society for Relief to the Wounded replaced it by a red crescent on a white ground. The red crescent has subsequently been adopted by several Islamic countries, and has been officially recognised as having equal status with the red cross. Thus, both the red cross and the red crescent flew over Allied hospitals and medical units, and protected their vehicles, during the Gulf War of 1990-91.

\section{International Humanitarian Law $(2,6)$}

The First Geneva Convention of 1864 with its ten articles is a milestone in the history of humanity, and the cornerstone of international humanitarian law and the rules of war (6). Previously, any arrangements made to protect the victims of war had been informal, temporar and non-binding, and indeed any formal contraq compelling belligerents to modify their actions on the battlefield had seemed inconceivable. From now on, $\mathbb{1}$ was accepted that international laws could apply to the battlefield, and that the provisions of such Conventions were permanent and binding in the event of conflict on the States party to them, even dictating identical humanitaria behaviour towards non-signatories. From this treaty were to stem the Hague Conventions and the Four Geneva Conventions with their Additional Protocols.

Dunant realised that the 1864 Geneva Convention was but a beginning (2). For years he fought, often singlehandedly, for the propagation of humanitarian ideals, and for the protection, by diplomatic conventions or international treaties, of prisoners of war, of wounded and shipwrecked members of armed forces at sea, and of civilians in wartime. In 1899, at the Hague, another Convention was signed, adapting the principles of the Geneva Convention to warfare at sea. In 1906, the provisions of the 1864 Convention were improved and supplemented. In 1907, the Fourth Hague Convention defined the categories of combatants entitled to the status of prisoners of war when captured. However, thousands of prisoners were to be thrown into camps for years during the First World War before Dunant's goal of a convention that would lay down provisions for the treatment of prisoners of war was achieved with the signing of the 1929 Convention.

\section{The Four Geneva Conventions of 1949 (3, 7-8)}

The First World War also highlighted the need to care N for civilian refugees and to protect civilian internees. The 
failure of governments to ratify an agreement proposed by the ICRC had its tragic consequences during the Second World War when millions of people died in Nazi concentration camps, and the Red Cross, with no legal right of access, was powerless to intervene. Horrified by such atrocities, the governments of the world met in a new diplomatic conference in 1949 and agreed to a new convention prepared by the ICRC relating to "the protection of civilians in wartime". At the same time the texts of earlier conventions were revised and aligned, and the result was the Four Geneva Conventions of 12 August 1949 , which respectively guarantee the protection of the wounded and sick in armed forces in the field; of wounded, sick and shipwrecked members of armed forces at sea; of prisoners of war; and of civilian persons in time of war (7-8).

\section{The Two Additional Protocols $(3,6,8)$}

New forms of conflict (such as wars of national liberation and civil war) after 1949 showed that the Four Conventions did not provide adequate protection in all circumstances. Hence, two Additional Protocols were adopted on 8 June 1977 after a Diplomatic Conference in Geneva, which simultaneously extended the scope of the Four Conventions to cover these new conflicts.

Protocol I covers international armed conflict including wars of liberation. Its provisions give greater protection to civilians, including civilian medical units, transport and personnel, which are now entitled to the same protection as that granted to their military medical counterparts; they also facilitate the channelling of relief supplies to civilians in time of war, and they ban reprisals and the use of weapons which "cause unnecessary suffering or strike without discrimination" - such as the use of starvation.

Protocol II covers non-international conflict, such as civil war. It provides fundamental guarantees for safeguarding all those not taking part in the conflict, and strengthens the protection due to medical units, transport and personnel.

\section{Medical Personnel in Armed Conflicts (9)}

The Four Geneva Conventions and their Additional Protocols lay down various provisions for military and civilian medical personnel whose services may be required in armed conflicts. These provisions are designed to help them accomplish their humanitarian mission on behalf of the victims of war, and distinguish between the duties incumbent on them and the rights conceded to them. It is therefore incumbent upon medical personnel to familiarise themselves with these provisions (9).

\section{Motivation}

\section{The Fundamental Principles of the Red Cross (10-11)}

The humanitarian principles inspiring and influencing the work of the International Red Cross and Red Crescent Movement were systematically defined and analysed by Jean Pictet in 1956, in his book on the Red Cross
Principles (10). As a result seven Fundamental Principt展 were unanimously adopted in 1965 by the Red Cross (1 F They are: humanity (the desire to prevent and alleviase human suffering wherever it may be found); impartialif (no discrimination is made as to nationality, race, religied, class or political opinion); neutrality (no side is takerf); independence (though they are auxiliaries in the humanitarian services of their governments and subject 50 the laws of their countries, the National Societies remas autonomous); voluntary service; unity (there can only be one Red Cross or Red Crescent Society in any ome country, open to all); and universality (the Movement $\frac{0}{d s}$ worldwide, with worldwide responsibilities).

\section{Structure}

The National Red Cross and Red Crescent Societies (3요곡 12-13)

The raison d'être of the National Societies remains the of helping military medical personnel care for the wounded and sick in time of war, but this role is now on one of many aspects of their work. This reflects the fast that military medical services have improved dramatically, and that civilians are increasingly tbe victims of war.

In peacetime too, especially after the First World their humanitarian skills have been utilised in many including disaster relief, in founding hospitals and nu两变 schools, in first-aid training, in running ambularce services, and in particular in the provision of bloge transfusion services.

The National Societies send volunteers, inclu ing surgeons and anaesthetists, to work with the Federation or ICRC abroad, preparing them through courses such as the Overseas DelegatesTraining Course run by the Britiog Red Cross at Barnett Hill, near Guildford.

Thus over the last 10 years the British Red Cross has sent out 10 surgeons on 24 three-month missions in ICR hospitals; 17 anaesthetists have been on 38 missions, and 7 Operating Theatre nurses have been on 20 missions.

International Federation of Red Cross and Red Cresce Societies $(3,12-13)$

The chaos and devastation in Europe in the aftermath the First World War was compounded by huge epidemies: of influenza, typhus and cholera, as well as by famine. the time there were no international bodies capable $\underline{\underline{J}}$ ! organising large-scale relief operations. A leader of the American Red Cross, Henry P Davison, therefo convened an international medical conference in 1919, बt which he proposed "to federate the Red Cross Societies of the different countries into an organisation ... in view ofa permanent world-wide crusade to improve health, prevênt sickness and alleviate suffering". As a result, on the $59 \mathrm{ph}$ May 1919, the League of Red Cross Societies was created. Since 1939 its permanent home has been in Geneva, at in 1991 it was renamed the International Federation of 
Red Cross and Red Crescent Societies.

The Federation supports the National Societies, particularly in times of disasters, natural catastrophes and epidemics, with their resulting masses of refugees, where international help is essential.

\section{The International Red Cross and Red Crescent Movement (3)}

In 1928, the International Committee of the Red Cross, the League and the National Societies joined together in an umbrella organisation under the name of "International Red Cross", whose statutes set out the respective roles of the Committee and the League. It organises International Conferences every four years, bringing together delegates of the ICRC, the Federation and the National Societies, as well as the representatives of States party to the Geneva Conventions. The International Conference is the supreme deliberative body of the Movement, determining major policy options on questions of principle and in the field of international humanitarian law. In 1986, the International Red Cross adopted the new title "International Red Cross and Red Crescent Movement", reflecting today's realities (3).

\section{International Committee of the Red Cross (ICRC) (3-4,} 13-15)

The "International Committee for Relief to Wounded Soldiers" founded in February 1863 by Henri Dunant and Gustave Moynier was renamed the International Committee of the Red Cross to reflect the wider aims eventually embodied in the Four Geneva Conventions. It is the guardian of the Geneva Conventions and of international humanitarian law. It also determines whether a new National Society meets the necessary conditions for recognition by, and thence admission to, the International Federation of Red Cross and Red Crescent Societies.

"Inter Arma Caritas" is its motto, and it acts around the world as a neutral intermediary between the victims of armed conflict who have rights (in particular the wounded, prisoners of war, and civilians displaced from their homes or living under occupation) and the States which have obligations, so as to strengthen the protection afforded war victims.

Though the permanent staff of the Committee are becoming increasingly international, all of the co-opted members of the Committee are Swiss, from a country with an ancient strongly upheld neutrality, for long experience has shown the value to the ICRC of their perceived neutrality. It must be emphasised though that the ICRC's neutrality is not tied to Swiss neutrality.

One of its major tasks is that of restoring contact between victims of armed conflict and their families, through the Central Tracing Agency (14), which centralises information it receives from all over the world - it has accumulated information on over 60 million persons to date.

The ICRC has had to increase its capacity to provide medical and general assistance to populations affected war, with the formation of a Relief Division, with a strong logistic structure, and a Medical Division.

\section{ICRC Medical Division (15A)}

The ICRC Medical Division, established in 1977, wooks for four categories of victims: the war wound prisoners, civilians and the war disabled.

Its essential purpose, according to Dr Remi Russbach, Chief Medical Officer of the ICRC, is "first and forem to keep the victims alive, lessen their suffering a d prevent the after-effects of their diseases or injuries fram ruining their future lives" (15A).

The Medical Division also meets priority needs medicines and medical supplies; it deals with the pubtic health requirements of conflict victims, and it providess rehabilitation and prosthetic services for amputees ofd paraplegics.

\section{War Surgery and the ICRC (15B-68)}

War surgery and care of the wounded is actually only a very small part of the work of the Medical Divisign. There is always a much greater need for clean water, adequate nutrition and protection of access to pre-existigig health structures, so the ICRC rightly concentrates its resources on these needs (15B).

Nevertheless, over the last fifteen years the ICR\&्ष established seven independent hospitals for war-wod near or within the border of the country where confectis occurring, and it has placed surgical teams in 18 phesexisting facilities in conflict zones. Up to 18,00 किar casualties have thus been cared for each year, by hungrgels of civilian surgeons and anaesthetists on 3-6 mog h contracts with the ICRC or with their National Societ.6s. As a result the ICRC has accumulated a wealthơ experience in dealing with war wounds, experience whin has shown the efficacy and necessity of management well-applied basic principles of war surgery. These principles are not new and have been known and practised by generations of military surgeons (16-18), though tre often have had to be relearned by surgeons new to war.

Over the last five years the ICRC has run an annial War Surgery Conference at Cartigny near Genevali to impart this experience to surgeons and anaesthetists ab夜 to embark on missions in ICRC hospitals.

The valuable lessons learnt by the ICRC through unrivalled experience of war surgery have been increassingly well documented over the last few years. Thegse lessons cover aspects such as first aid, triage, wou classification, wound excision and delayed primary closure, penetrating head injuries, blood transfusion, war surgery and anaesthesia, vascular and abdominal injuri:s, limb injuries, amputations and antipersonnel mine injur?es - all of direct relevance to military surgeons.

First Aid (19)

Two major problems of war casualties are firstly 
they seldom receive adequate first aid and secondly that their access to hospital is either non-existent or delayed and hazardous. The Medical Division of the ICRC therefore strives to improve first-aid training for combatants and civilians and to provide transport for the wounded. It has also established first aid posts near conflict areas, where wounds are dressed, fractures are splinted, intravenous infusion is started, and antibiotics and analgesics are given, prior to transport to ICRC hospitals (19).

\section{Triage (20-24)}

The ICRC hospitals have often been inundated by large numbers of both civilian and combatant war injured, such that the available surgical facilities are overwhelmed. The ICRC has documented its practical, well-tried system (2023) for the benefit of anyone, including military medical personnel, who may have to deal with large numbers of war wounded with limited resources.

The triage categories (22) used in ICRC hospitals are:

Category $I$, requiring urgent surgery and with a good chance of reasonable survival;

Category II, who do not require surgery. (This includes both patients with very slight wounds and those so severely injured as to be unlikely to survive);

Category $I I I$, who can wait for non-urgent surgery.

This triage system was used effectively by the Saudi Arabian teaching hospital which treated the majority of American soldiers wounded in the Al-Khobar Scud missile disaster of 25 February 1991 during the recent Gulf War (24).

\section{Wound Classification (25-30)}

"Treat the wound not the weapon". Recognition that wound management is determined by the wound severity (i.e., both by the structures involved and more importantly by the overall size of the wound) rather than by the weapon or presumed missile velocity has led to the formulation of the Red Cross Classification of War Wounds (25).

In this system certain features of the wound are scored: the size of Entry and eXit wounds; whether there is a Cavity, Fracture or Vital structure injured; and whether Metallic foreign bodies are present. Subsequent analysis allows the wound to be graded according to the amount of tissue damage. Grade 1 signifies low energy transfer, Grade 2 high energy transfer, and Grade 3 a massive wound. The wounds can also be typed according to structures injured, Soft Tissue, F, V, or VF. Grading and typing place any regional wound into one of 12 categories of comparable clinical significance.

This provides a new means of understanding, communicating, and gathering information about war wounds and their management (25-26A). For instance, it has shown that certain small uncomplicated Soft Tissue fragment wounds can be treated initially without surgery (26B).
An important application of this Classification is in assessing whether one or both sides of a conflict are using ammunition that contravenes the Hague Declaration of 1899 , which specifically forbids the use of small arms ammunition that disrupts in the body after impact to cause unnecessarily severe wounds (27-28).

Since its inception the Red Cross Classification has been used in all ICRC hospitals. It has also proven its? worth in the evaluation of civilian shotgun wounds in the United Kingdom (29) and in the assessment of woundect. military personnel treated in a British field hospital in the 1991 Gulf War (30).

Wound Excision, Dressings and Delayed Primary Closureo (31-35)

"The proper treatment of wounds is to be regarded a. the most important requirement for the surgeon" Billroth 1871 .

The basic principles of war wound management, known? to military surgeons for centuries (16-18), and rightlys emphasized by the ICRC (31-35), involve excision of alb dead tissue and foreign materials, and the decompressiont of viable tissue affected by the injury. If this is welF performed, infectious complications are prevented. After adequate wound excision, dry and bulky dressings are left undisturbed until the time of delayed primary closure days later (31-34).

In ICRC hospitals patients are not evacuated afmero initial surgery. This is particularly advantageous, fo gives the surgeon the best possible opportunity to impropee his technique, by assessing the results of his initeat excision when the dressings are removed.

\section{Penetrating Head Injuries (36)}

Surgeons in ICRC hospitals, like most militaryo surgeons, usually have minimal previous neurosurgicap experience, and moreover have no facilities fo $\overrightarrow{\overrightarrow{6}}$ evacuation to neurosurgical units. The surgery recommended by the ICRC therefore focuses or haematoma evacuation and the prevention of brain? abscess (36).

\section{Blood Transfusion (37-38)}

It has been observed that the patients requiring mose blood in ICRC hospitals are those injured by antipersonnel mines, who sustain large wounds mainly of the lower extremities (37-38), and who often undergo amputation. Surprisingly little has been written abouid transfusion requirements in war, which makes the ICRC? experience all the more important.

The ICRC recommendations are that when? antipersonnel mines are used widely in a conflict, theo blood bank should expect to provide 100 units of bloof for every 100 patients (37). For every 100 patients with aro amputation, 345 units should be provided, and this requirement will continue long after hostilities have ceased (38). 
War Surgery and Anaesthesia $(31,39-50)$

The ICRC has published a practical fieldbook, Surgery for Victims of War (31), loosely based on older military war surgery fieldbooks (18), summarising the experience of eminent specialists in various disciplines. This reflects the fact that ICRC hospitals have to serve both as field hospitals and as definitive centres combining primary, secondary and basic reconstructive surgery (20), for which problem area certain guidelines have been developed (39-40). A feature of note is that there are no facilities for prolonged, postoperative ventilation of patients: there is a correspondingly greater reliance on the use of ketamine and locoregional blocks for anaesthesia (41). On a personal level, individual surgeons and anaesthetists, on their return from postings to ICRC hospitals, have documented their experiences (42-50). All have benefited from such attachments.

\section{Vascular and Abdominal Injuries (51-56)}

The ICRC experience of vascular injuries reflects the fact that evacuation of the wounded to ICRC hospitals is by road, and is at best difficult, with over $60 \%$ of patients arriving more than 12 hours after injury $(44,51)$. This lag time between injury and treatment is the single most important prognostic variable for limb salvage. Revascularisation is only attempted in patients seen within 12 hours of injury, with primary amputation being almost inevitable in patients arriving after 12 hours (5254).

Penetrating abdominal injuries requiring laparotomy are dealt with in ICRC hospitals by established surgical techniques $(31,35,55-56)$. The main area of controversy lies in the treatment of colonic injury by selective primary repair in up to half the patients, rather than by colostomy, especially if the injury to the left colon is minor, and resection and immediate ileocolic anastomosis for all right colon injuries. The guidelines for performing colostomy for transverse and left colonic injuries are: $i$. shocked patient; ii. other severe intra-abdominal injuries; iii. delay in presentation; and iv. marked faecal contamination (56).

\section{Limbs, Amputations and Mine Injuries (31, 57-67)}

Over $70 \%$ of all war wounded patients present with limb wounds. With so many limb injuries, surgical amputations of both lower and upper limbs at every level are common. Most of the severe limb injuries and traumatic amputations result from antipersonnel mines, which are widely used and very difficult to detect.

The exceptionally high blood transfusion requirements for amputees (345 units for every 100 amputees) presents obvious logistic problems. In addition, war-injured patients with an amputation face more serious problems than non-amputees: their mortality is higher, they stay longer in hospital, the risk of infection is higher, and they undergo more surgical interventions (38).

Mines respect no ceasefire, they remain long after a conflict and they do not discriminate between the footstep of a child and that of a combatant. The ICRC has been forthright in its condemnation of the indiscriminate use of $z$ landmines: "Mines are the greatest violators of $\stackrel{\triangleright}{\unrhd}$ international humanitarian law, practising blind $\bigcirc$ terrorism" (57-58).

Three recognisable patterns of mine injury are seen in ICRC hospitals, and the ICRC has issued guidelines $(31, \overrightarrow{\vec{s}}$ 59-61), and produced an excellent video (62), Anti Personnel Mine Injuries - Surgical Management, to assist its surgeons in performing optimal amputations.

The ICRC has also recently published a book, War Wounds of Limbs - Surgical Management (63), written primarily for the surgeon about to enter the field, which guides the surgeon through war wounds and mine injuries, the surgeon's role, methods of amputation, the complications and difficulties encountered and the rehabilitation of the patient.

A recent review describes the ICRC method of using external fixation in combination with plaster splints or skeletal traction such that it can be "locked" or "unlocked" as required (64). This method eliminates many of the disadvantages of external fixation, in particular minimising delay in callus formation and pin problems.

The ICRC has widely publicised the lessons it has learnt in war surgery specifically to educate medical an 0 nursing personnel (65), both civilian and military, whâ may eventually have to face such problems themselve\& $\mathbb{Q}$ Who would have imagined three years ago, for instance that the civilian surgeons of Europe's largest Universitg $₫$ Teaching Hospital - in Sarajevo - would have had familiarise themselves with these lessons?

Moreover, such is the scale of the indiscriminate effects of antipersonnel mines on both individuals and communities that the ICRC is actively raising public awareness of this problem (66). It organised an international symposium on mine warfare and the effects of mines in Montreux in April 1993, since when a campaign to ban mines has commenced, and the United Nations is actively reviewing existing law, the 1980 United Nations Convention (67).

\section{Conclusions}

The origins of the International Red Cross and Red Crescent Movement lay in the humanitarian desire of Henri Dunant to aid the military medical services in caring for war wounded. Now, ironically, the hospitals of the ICRC daily deal with more victims of war than many military surgeons see in a lifetime of practice.

The author therefore advocates that it is time for the military medical services around the world to repay their debt to the Red Cross by actively encouraging their surgeons, anaesthetists and other theatre personnel to volunteer for temporary secondment with the ICRC.

At a time when realistic peacetime military training is increasingly difficult to achieve, and when the few suitably experienced military surgeons are leaving the 
services, such postings would also have the obvious benefits to the military medical services of excellent training, of enlarging the pool of experienced personnel, and of encouraging such personnel to remain in the Services.

The author suggests that the ICRC video on AntiPersonnel Mine Injuries should be shown to all military medical personnel. Whilst there are some differences in doctrine between the ICRC and the military medical services, e.g. on evacuation policy, there is such unanimity on basic management principles that the ICRC fieldbook "Surgery for Victims of War" and the book "War Wounds of Limbs - Surgical Management" should be standard issue to all military surgeons (alongside the Field Surgery Pocket Book which is currently the only surgical text issued to RAMC doctors). Lastly, the Red Cross wound classification could profitably be adopted by the military medical services. This would help to standardise the recording of wounds from different conflicts, and aid ballistic and wound research.

ICRC surgical doctrine and practice, as exemplified in these books and its hospitals, may well soon become even more relevant to the military medical services. This is because the current trend would appear to be away from working within a system of structured evacuation chains and more and more towards working in humanitarian missions with the United Nations, with emphasis on providing and teaching adequate first aid and nonoperative management, and devoting the limited surgical resources to those who require semi-urgent surgery for survival or for improved quality of survival (68).

Only by regularly dealing with a full spectrum of war wounds can military medical personnel hope to acquire and maintain their skills in war surgery.

\section{Acknowledgements}

I would like to express my gratitude to Lt General Sir Cameron Moffat KBE, FRCS, Chief Medical Adviser to the British Red Cross, to Robin Coupland FRCS, Surgeon with the Medical Division ICRC, to Bertrand Kern, External Resources Division ICRC, to Colonel J M Ryan MCh FRCS, Late RAMC, Professor of Military Surgery, and to Major A M O Miller RE, my brother-in-law, for their generous help with constructive criticism of this article.

\section{REFERENCES}

1. Dunant H. Un Souvenir de Solferino. Geneva: 1862; A Memory of Solferino. Geneva: International Committee of the Red Cross, 1986.

2. BoIsSier P. Henry Dunant. Geneva: Henry Dunant Institute, 1974.

3. BORY F. Red Cross and Red Crescent: Portrait of an International Movement. Geneva: International Committee of the Red Cross.
4. BOISSIER P. History of the International Committee of the Red Cross. Volume I: From Solferino to $\frac{3}{\mathrm{Q}}$ Tsushima. Geneva: Henry Dunant Institute, 1985.

5. Oliver B. The British Red Cross in Action. London: Faber \& Faber, 1966: 79.

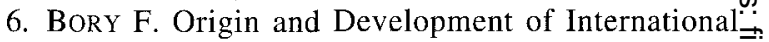
Humanitarian law. Geneva: International Committees of the Red Cross, 1982.

7. The Geneva Conventions of 12 August 1949 .음 Geneva: International Committee of the Red Cross, $\frac{\bar{D}}{8}$ 1949, 1986 (reprint).

8. Basic Rules of the Geneva Conventions and theire Additional Protocols. Geneva: International Commit- $\rightarrow$ tee of the Red Cross, 1983, 1987 (reprint).

9. BaCcino-Astrada A. Manual on the Rights and $\vec{\omega}$ Duties of Medical Personnel in Armed Conflicts $\stackrel{2}{S}$ Geneva: International Committee of the Red Cross/League of Red Cross and Red Crescent Soci-⿳⺈冖 eties, 1982.

10. Pictet J. Red Cross Principles. Geneva: International Committee of the Red Cross, 1956.

11. The Fundamental Principles of the Red Cross and Red Crescent Movement. Geneva: International Com-음 mittee of the Red Cross, 1990.

12. The Red Cross. Geneva: Henry Dunant Institue 1973.

13. DuRAnd A. History of the International Committee the Red Cross. Volume II: From Sarajevo Hiroshima. Geneva: Henry Dunant Institute, 1984.

14. DuUrovic G. The Central Tracing Agency of the International Committee of the Red Cross. Geney Henry Dunant Institute, 1986.

15A RussBaCH R. "The International Committee of the Red Cross and Health". International Review of the $\stackrel{0}{0}$ Red Cross 1987; 260: 513-522.

15B PERRIN P. "Strategy for Medical Assistance in $\overrightarrow{0}$ Disaster Situations." International Review of the Red 3 Cross, 1991; 284: 494-504.

16. WangensteEn O H, Wangensteen S D, KLINGeR C F. "Wound Management of Ambroise Paré and Dominique Larrey, great French Military Surgeons of the 16th and 19th Centuries". Bulletin of the History of Medicine 1972; 46: 207-234.

17. EDWARDS H C. "The contribution of war to the advancement of surgery". J R Army Med Corps 1956; 102: 234-246.

18. Kirby N G, Blackburn G. (eds): Field Surgery Pocket Book. London, HMSO, 1981.

19. KORVER A J H. "Outcome of war-injured patientso treated at first aid posts of the International Committee of the Red Cross". Injury 1994; 25: 25-30.

20. Trouwborst A, Weber B K, Dufour D. "Medical statistics of battlefield casualties". Injury 1987; 18: 96-99.

21. GRAY R. "Surgery of war and disaster". Tropical Doctor. 1991; 21: (Suppl 1): 56-60.

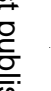


22. Coupland R M, Parker P J, Gray R C. "Triage of war wounded: the experience of the International Committee of the Red Cross". Injury. 1992; 23: 507510.

23. Gray R. "War surgery and triage". Postgraduate Doctor Middle East 1993; 16: 150-157.

24. Ahlberg A, Corea J R, SAdat-Ali M, et al. "The scud missile disaster in Al-Khobar, Saudi Arabia, 1991: the orthopaedic experience". Injury 1994; 25: 97-98.

25. Coupland R M. The Red Cross Wound Classification. Geneva: International Committee of the Red Cross, 1991.

26A Coupland R M. "The Red Cross Classification of War Wounds: The E.X.C.F.V.M. Scoring System: World J Surg 1992; 16: 910-917.

26B Coupland R M. "Hand Grenade Injuries among Civilians". JAMA 1993; 270: 624-626.

27 . Weapons that may cause unnecessary suffering or have indiscriminate effects: Report on the work of experts. Geneva: International Committee of the Red Cross, 1973.

28. Coupland R M, HoikKa V, SJoEkLint O G, Cuenod P, Cauderay G C, Doswald-Beck L. "Assessment of bullet disruption in armed conflicts": Lancet 1992; 339: 35-37.

29. StEWART M P M, KInNINMONTH A. "Shotgun wounds of the limbs" Injury. 1993; 24: 667-670.

30. Bowyer G W, Stewart M P M, Ryan J M. "Gulf war wounds: application of the Red Cross wound classification". Injury 1993; 24: 597-600.

31. Dufour D, Kroman Jensen S, OWen-Smith M, Salmela J, Stening C F, Zetterstrom B. Surgery for Victims of War. Geneva: The International Committee of the Red Cross, 1988.

32. GRAY R, WINIGER E. War Surgery: An Introduction (video). Geneva: ICRC Audio-Visual Division, 1988.

33. COUPLAND R M "Technical aspects of war wound excision": Br J Surg 1989; 76: 663-667.

34. Coupland R M "War wound excision". Br J Surg 1990; 77: 833.

35. MORRIS D S. "Surgeons and the International Committee of the Red Cross". Aust NZ J Surg 1992; 62: $170-172$.

36. Coupland R M, Peronen P E. "Craniocerebral war wounds: non-specialist management". Injury 1992; 23: $21-24$

37. Eshaya-Chauvin B, Coupland R M. "Transfusion requirements for the management of war injured: the experiences of the International Committee of the Red Cross". Br J Anaesth 1992; 68: 221-223.

38. Korver A J H. "Amputees in a hospital of the International Committee of the Red Cross". Injury 1993; 24: 607-609.

39. COUPLAND R M. "The role of reconstructive surgery in the management of war wounds". Ann R Coll Surg Engl 1991; 73: 21-25.
40. COUPLAND R M "A management algorithm for chronically exposed war wounds of bone". Injury 1990; 21: 101-103.

41. Eshaya-Chauvin B, Nyffenegger E. "Anesthésie pour blessés de guerre: "etude rétrospective". Rev 응 Med Suisse Romande 1990; 110: 429-432.

42. Morris D, Sugrue W, McKenzie E. "On the border $\overrightarrow{\overrightarrow{\mathrm{D}}}$ of Afghanistan with the International Committee of $\frac{\overrightarrow{0}}{0}$ the Red Cross". NZ Med J 1985; 98: 750.

43. GERTSCH P. "Assessment of hospital workload in war surgery". Br J Surg 1987; 74: 831-833.

44. RaUtio J, PaAvolainen P. "Afghan war wounded: 을 experience with 200 cases". I Trauma 1988; 28: 523-525.

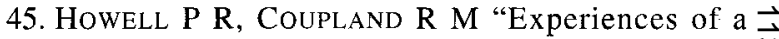
British Red Cross surgical team on the Afghanistan ${ }_{\mathscr{N}}$ border". Today's Anaesthetist 1988; 3: 187-192.

46. Coupland R M, Howell $P$ R "An experience of war surgery and wounds presenting after 3 days on the border of Afghanistan". Injury 1988; 19: 259-262.

47. CRAIG G. "Treating the Afghan war wounded". $J R$ i Soc Med 1993; 86: 404-405.

48. Bowyer G W. "Amputations for Mine Injuries - $\vec{\overrightarrow{ }}$ Experience from the Afghan Conflict" Abstract, 을 Proceedings of the Defence Medical Services Su당 gical Meeting. London, October 1993.

49. Bowyer $G$ W. "To Cut or Not to Cut - the Manage ment of Small Fragment Wounds" Abstract, Procee⿻ ings of the Defence Medical Services Surgical Mee ${ }^{\circ} \vec{P}$ ing, London. October 1993.

50. BOWYER G W. "Report on a surgical attachment to 通 International Committee of the Red Cross War SuE. gery Hospital" 21 Nov 1993 (Report to Prof Mit Surg, unpublished).

51. Bhatnagar M K, SMith G S. "Trauma in the Afghan Guerilla War: Effects of lack of access to care". ¿ Surgery 1989; 105: 699.

52. GerTSCh P. "Lésions vasculaires des blessés de guerre afghans traitées à l'hôpital du CICR à Peshawar". Milit Med 1986; 2: 46-47.

53. FASOL R, IRvine S, Zilla P. "Vascular injuries caused by anti-personnel mines". J Cardiovasc Surg 1989; 30: 467.

54. Gosselin R A, Yukka Siegberg C J, Coupland R, Фे AGERSKOV K. "Outcome of arterial repairs in $23 \stackrel{\text { ” }}{\rightleftharpoons}$ consecutive patients at the ICRC-Peshawar hospital for war wounded". J Trauma 1993; 34: 373-376.

55. FASOL R, Zilla P, IRvine S, vON OPPELL U. "Thoraco-abdominal injuries in combat casualties on the Cambodian border". Thorac Cardiovasc Surg o 1988; 1: 33-36.

56. MORRIS D S, SUGRUE W J. "Abdominal injuries in the $\frac{7}{0}$ war wounded of Afghanistan: a report from the International Committee of the Red Cross Hospital in $\%$ Kabul". Br J Surg 1991; 78: 1301-1304.

57. Mines: A Perverse Use of Technology. Geneva: N International Committee of the Red Cross, 1992. 
58. DOUCET I. "The Cowards' War: Landmines and Civilians". Med War 1993; 9: 304-316.

59. COUPLAND R M. “Amputation for antipersonnel mine injuries of the leg: preservation of the tibial stump using a medial gastrocnemius myoplasty". Ann R Coll Surg Engl 1989; 71: 405-408.

60A COUPland R M, Korver A. "Injuries from antipersonnel mines: the experience of the International Committee of the Red Cross". Br Med J 1991; 303: 1509-1512.

60B Coupland R M. "Hospital Mortality of Patients Injured by Antipersonnel Mines. Br Med J 1992; 304: 1509.

61. Coupland R M. Amputation for War Wounds. Geneva: International Committee of the Red Cross, 1992.
62. Antipersonnel Mine Injuries - Surgical Management (Video). Geneva: ICRC Audio-Visual Division, 1993.

63. Coupland R M. War Wounds of Limbs - Surgical Management. Oxford: Butterworth-Heinemann, 1993.

64. COUPLAND R M. "War wounds of bones and external fixation". Injury 1994; 25: 211-217.

65. SEwELL A. "The wounds of war". Nursing Standard 1991; 5: 19-20.

66. LIMERICK S R. "The International Red Cross and Red Crescent Movement". J R Coll Physicians Lond 1991; 25: 246-251.

67. COUPland R M, Russbach R. "Victims of Anti- के personnel Mines: What is being done?" Medicine \& Global Survival. 1994; 1: 18-22.

68. Coupland R M. "Epidemiological Approach to Surgical Management of the Casualties of War". Br Med $J$ 1994; 308: 1693-1697. 